\title{
Conservation of aquatic biodiversity for achieving india's food, nutritional and livelihood security with special reference to inland fisheries and aquaculture.
}

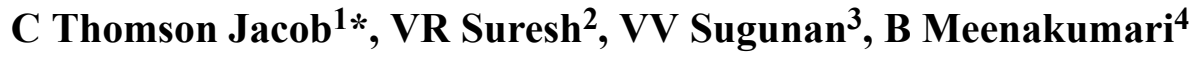 \\ ${ }^{1}$ Centre for Biodiversity Policy and Law, National Biodiversity Authority, Chennai, India \\ ${ }^{2}$ Riverine Ecology and Fisheries Division, Indian Council of Agriculture Research - Central Inland Fisheries Research \\ Institute, Barrackpore, Kolkata, India \\ ${ }^{3}$ Council for Agricultural Research, New Delhi, India \\ ${ }^{4}$ National Biodiversity Authority, Chennai, India
}

\begin{abstract}
The inland water resources are rich in aquatic biodiversity and the inland fishery sector plays an important place in socio-economic development of the country. India is the second largest producer of fish in the world and the historical scenario of Indian fisheries reveals a paradigm shift from marine dominated fisheries to inland fisheries. The aquatic resources of the inland resources are getting degraded due to pollution, water abstraction, flow modification, eutrophication, spread of invasive alien species, climate change, urbanization, etc. There is an urgent need to address the loss of India's aquatic biodiversity towards enhancing India's food, nutritional and livelihood security. The present study has brought out recommendations towards conserving India's aquatic resources especially those of particular importance for species, biodiversity and ecosystem services.
\end{abstract}

Keywords: Aquaculture, Aquatic, Biodiversity, Fisheries, Genetic resources, Inland, water.

Accepted on April 10, 2020

\section{Introduction}

The inland water resources such as lakes, rivers, canals, reservoirs, ponds, streams, springs, cave waters, flood plain wetlands, estuaries, coastal lagoons, mangrove creeks, marshes, backwaters and swamps are rich in aquatic biodiversity [1]. These dynamic ecosystem support various ecosystem services such as climate regulation, flood mitigation, nutrient recycling, water purification, waste treatment and also provide habitat for fishes, amphibians, water birds, semi aquatic animals and aquatic plants. Many of these aquatic resources are poorly conserved and this has led to the loss of biodiversity. In order to safeguard the biodiversity it is essential to conserve the water resources and to maintain good quality water in the lotic and lentic ecosystems towards minimizing the loss of aquatic genetic resources. The objective of the present study is to enhance the aquatic biodiversity and fishery resources in the inland water bodies and to conserve the pristine ecosystem rich in endemism.

\section{Aquatic genetic resources of India}

India aquatic genetic resources comprise 9,456 species, which is approximately 9.7 percent of the total number $(97,708)$ of animal species. The freshwater invertebrates include Phylum Arthropoda (5,923 species), Nematoda (422 species), Rotifera (419 species), Mollusca(217 species), Annelida (167 species) and Platyhelminthes (163 species). The Phylum Chordata comprises fishes (1,047 species), amphibians (275 species), aves (243 species), reptiles (46 species) and mammals (6 species) [2]. The inland fish diversity comprises 113 brackish water, 936 freshwater and 462 exotic finfishes. The Gangetic river system harbours around 265 species of fish; river Brahmaputra has 126 species and the peninsular rivers have more than 76 fish species [3]. The inland waters also support some of the charismatic species such as Gharial and Irrawaddy dolphin.

The warm water fish species found in the Indian waters include: major and minor carps namely, Labeo rohita, L. calbasu, L. bata, L. fimbriatus, Gibelion catla, Cirrhinus mrigala, C. cirrhosa and C. reba;Catfishes, such as Clarias magur, Heteropneustes fossilis, Sperata aor, S. seenghala, Wallago attu, Pangasius pangasius, Silonia silondia, Bagarius bagarius and Rita rita; Murrels such as Channa striata, C.marulius, C.punctatus. The other important species are Anabas testudineus, Chitala chitala, Notopterus notopterus, Labeo gonius and L.dycheilus [4].

\section{India's inland water resources and fishery resources}

India's river systems comprise 14 major, 44 medium and 153 small rivers with a combined length of 0.19 million kilometer and they harbour one of the richest biodiversity in the world [5]. Estuaries consist of diverse habitats, such as mangroves, salt marshes, sea-grasses and mud flats and it provides nursery and breeding grounds for commercially or ecologically important species, such as fishes, shrimps, oysters, mussels, lobsters, prawns, crabs, dolphins and crocodiles. India has 53 estuaries spread along its coastline, which support stocks of 
hilsa, mullets, prawns, crabs, and so on. The major estuaries are Hooghly, Mahanadi, Godavari, Krishna, Cauvery, Narmada and Tapti, covering a total area of $0.3 \mathrm{~m}$.ha. besides the coastal lagoons, Chilika, Pulicat and backwaters of Kerala [6].The Sundarbans mangrove forestaccounts for half of the total area of mangroves in India and provides home for many of the globally threatened species, which includes estuarine crocodile (Crocodylus porosus), fishing cat (Felis viverrina), common otter (Lutra lutra), water monitor lizard (Varanus salvator), Gangetic dolphin (Platanista gangetica), snubfin dolphin (Orcella brevirostris), river terrapin (Batagur baska), marine turtles like Olive Ridley (Lepidochelys olivacea), green sea turtle (Chelonia mydas) and hawksbill turtle (Eritmochelys imbricata) [7]. Also the East Godavari River Estuarine
Ecosystem (EGREE) encompassing Godavari mangroves, is the second largest mangrove forest in the country with 35 species of mangroves. The EGREE region is an important nesting site for migratory turtle species notably the endangered Olive Ridley turtle, fishing cat and smooth coated otter, Olive etc. It also serves as feeding and spawning ground and acts as a sanctuary for the growth and development of numerous fin and shell fish. It is an important bird area with a recorded population of 272 bird species, of which 95 are migratory. Similarly, wetlands are treasures of biodiversity and it support unicellular algae, bryophytes, mosses, ferns and woody angiosperms. Some of the faunal species found in the wetlands are dolphins, otters, swamp deer, hog deer, fishing cats, rhinoceroses, elephants, wild buffaloes [8], etc (Table 1).

Table 1. Inland fishery resources in India and their utilization modes.

\begin{tabular}{|c|c|c|}
\hline Resource type & Resource size & Fish production system \\
\hline Rivers and canals $(\mathrm{M} . \mathrm{ha})^{*}$ & 0.19 & Capture \\
\hline Reservoirs (M.ha)* & 3.15 & Culture-based fisheries/Stock enhancement/Cage culture \\
\hline Ponds and tanks (M.ha)* & 2.36 & Aquaculture \\
\hline Brackish water area(M.ha) $)^{*}$ & 1.24 & Aquaculture \\
\hline Floodplains and lakes (M.ha) $)^{* *}$ & 1.2 & Culture-based fisheries and pen culture \\
\hline Wetland (Inland and coastal) (M.ha) & 15.26 & Capture and aquaculture \\
\hline Beels (M.ha) ** & 1.3 & Culture-based fisheries/ Aquaculture \\
\hline \multicolumn{3}{|c|}{$\begin{array}{l}\text { Source:*Department of Animal Husbandry, Dairying and Fisheries (DAHDF) Annual Report, 2017-18. } \\
{ }^{* *} \text { National Inland Fisheries and Aquaculture Policy (NIFAP), } 2019 .\end{array}$} \\
\hline
\end{tabular}

\section{Fish production in India}

India is the second largest producer of inland fishes and contributes significantly to the overall fish production in the country. The total fish production has increased from 5.66 MMT in 2000-01 to 11.41 MMT (7.77 MMT inland and 3.64 MMT marine) in 2016-17. There has been a shift from capture fisheries to aquaculture in the last two and a half decades and the fisheries sector contributed around 0.92 percent to the Gross Value Added (GVA) and 5.23 percent to the agriculture GVA during 2015-16. India's fish production has been dominated by the inland fisheries and there is a shift from the marine dominated fisheries to inland fisheries. The inland fisheries contributes to an overall fish production of 68.1 percent [9] (Figure 1).

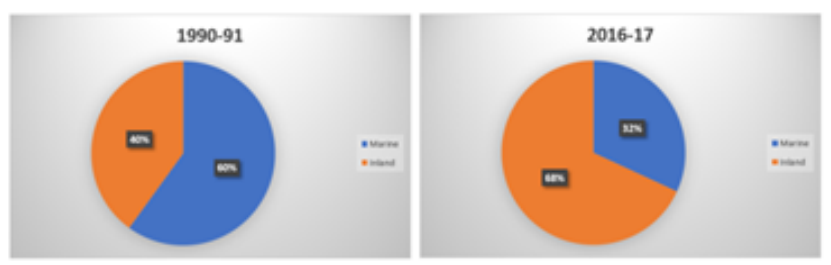

Figure 1. Marine and Inland fish production during 1990-91 and 2016-17.

\section{Aquaculture}

India's aquaculture involves over 600 freshwater and marine animal species drawn from various tropic levels. The freshwater aquaculture primarily depends on cultivating carp species and some of the species used for freshwater aquaculture includes: Indian carps (Catla catla), rohu (Labeo rohita) and mirgal (Cirrhinus mirgala) (contribute between 70 and $75 \%$ of the total freshwater fish production); Silver carp, grass carp, pearl spot, tilapia, common carp and catfish (contribute from 25 to $30 \%$ of the production). In addition, the giant freshwater prawn (scampi) is produced in freshwater ponds and these species are widely cultivated in West Bengal, Orissa, Andhra Pradesh, Telangana, Karnataka, Kerala, Bihar, Jharkhand, Madhya Pradesh, Chhattisgarh, Rajasthan and Uttar Pradesh [10].

The brackish water fish species such as mullets, milkfish, pearlspots \& sea bass and crustaceans viz Penaeus monodon, $P$. merguiensis and $P$. semisulcatus, Fenneropenaeus indicus and crab Scylla serrata are commercially exploited. Also shrimps, oysters, mussels, crabs, lobsters, sea bass, groupers, mullets, milk fish, cobia, silver pompano, pearl spot, ornamental fishes and weeds are being cultivated in the brackish waters. It is reported that only $14 \%$ of the brackish water area is used for 
Citation: Jacob TC, VR Suresh, VV Sugunan, B Meenakumari. Conservation of aquatic biodiversity for achieving india's food, nutritional and livelihood security with special reference to inland fisheries and aquaculture. J Fish Res 2020;4(1):30-35.

brackish water aquaculture. Some of the traditional brackish water aquaculture practices in India includes: Bheries (manmade impoundments in coastal wetlands) in West Bengal and Pokkali cultivation (salt resistant deep-water paddy) in Kerala. In the traditional system of culture, tidal water is impounded in the inter-tidal mudflats by raising bunds and the marketable sized fish and shrimps are harvested during spring. These systems have been sustaining production levels between $500-750 \mathrm{~kg} / \mathrm{ha} /$ year with shrimps contributing $20-25$ percent of the total production [11]. The Geographical indication tagged Pokkali is a salt water tolerant paddy grown in the coastal fields of Alappuzha, Ernakulam and Thrissur districts. This variety is endemic to central Kerala and it is now grown in only over 5,000 hectares (ha.), a drop from over 25,000 ha., due to poor returns.

\section{Cold water fisheries}

The cold water resources are distributed mainly in the form of upland streams, rivers, lakes and reservoirs that are located at medium to high altitudes of Himalayan corridor such as Jammu \& Kashmir, Himachal Pradesh, Uttarakhand, Sikkim, West Bengal and all North-Eastern States. The Himalayan region has around $8,243 \mathrm{~km}$ long streams and rivers, 20, 500 ha natural lakes, 50,000 ha of reservoirs and 2500 ha brackish water lakes. These water bodies inhabit diverse kind of fish fauna of 258 cold water fish species [12]. At present, the total fish production from upland areas constitute about 3 percent of inland fish production. The commercial farming of high value cold water species like exotic rainbow trout has been taken up successfully and estimable progress has been made. Jammu \& Kashmir, Himachal Pradesh and Sikkim are the leading states in trout farming. The north-eastern region, Eastern Himalayas and the Western Ghats are known for its rich repository of ornamental fish species. Out of the total 225 species reported, about $187(74 \%)$ are known for their ornamental value and some of the important species reported are Puntius conchonius, P.gelius, P.ticto, P.sophore, Brachydanio rerio, Botia almorhae, Carassius carassius, C. auratus, Badis badis, Barilius barna, B. vagra, etc.

\section{Concerns}

The important concerns related to inland sector are increasing pollution load due to industrialization and urbanization, agricultural runoff, change in flood regime, obstruction of migratory pathways of fishes due to developmental projects, habitat destruction, sedimentation and destructive fishing practices, spread of invasive alien species, illegal collection of wild varieties, etc. India possesses several endemic carp species, such as Labeo calbasu, L. fimbriatus, L. gonius, L. dussumieri, L. bata, Cirrihinus cirrhosa, C. reba, Puntius sarana and $P$. jerdoni but the country still depends on few species [13]. Ornamental fish has emerged as a sunrise segment within the fisheries sector that commands a lucrative domestic and overseas trade. The north-eastern region, Eastern Himalayas and the Western Ghats are known for its rich repository of ornamental fish species. It is reported that, nearly 85 percent of the ornamental fish exported is caught from the wild stock and the ornamental alien fish hybridise with indigenous species in the wild, diluting the wild genetic stock leading to long-term introgression of gene pools [14].

The unregulated introduction of alien species is a major biodiversity concern and many alien species exist in the country, which were brought in without clearance from the authorities through the porous borders. Keepers or hobbyists also discard ornamental fishes into open waters, when they are no longer want to hold them or when the fish grows too large for holding in aquaria. The inland rivers and wetlands are invaded by exotic species, threatening the existence of many of the habitats and considerably affecting the native species. Some of the plant invasive species recorded are water hyacinth (Eichhornia crassipes), pink morning glory (Ipomea carnea), butterfly fern (Salvinia auriculata), parrot's feather (Myriophyllum aquaticum), reed canary grass (Phalaris arundinacea) and so on. Over 300 exotic fish species have been brought to India for aquaculture, sport fishing, mosquito control and aquarium purposes and some of them have entered into the natural inland water systems and in turn caused extensive damage to the native species. These include Common carp (Cyprinus carpio), African catfish, (Clarias gariepinus), Sucker mouth catfish (Pterygoplichthys spp.), Tilapia (Orecohromis mossambicus), Grass carp (Ctenopharyngodon idella), Silver carp (Hypophthalmichthys molitrix) and so on [15]. In the river Ganga, presence of exotic species such as Cyprinus carpio and Oreochromis niloticus [16] are increasing. The occurrence of African catfish is reported in rivers Ganga, Yamuna, Sutlej, Godavari and Periyar and lakes such as Vembanad [17]. In Kerala, the high occurrence of tilapia species has been reported, due to which the native species such as Puntius dubius and Labeo kontius face extinction.

\section{Mainstreaming Biodiversity Approach}

Mainstreaming Biodiversity is the process of embedding biodiversity considerations into policies, strategies and practices of key public and private actors that impact or rely on biodiversity, so that biodiversity is conserved and sustainably used both locally and globally [18]. For undertaking this study, a comprehensive policy analysis was carried by reviewing various fisheries policies, schemes, programmes, plans and projects. A sectoral policy analysis was carried out using the D (Driving force), P (pressure), S (State), I (Impact) and (R) Response [19] methodology (Figure 2) and the emerged recommendations were finalized through an interactive consultative process by involving fishery and biodiversity experts. 


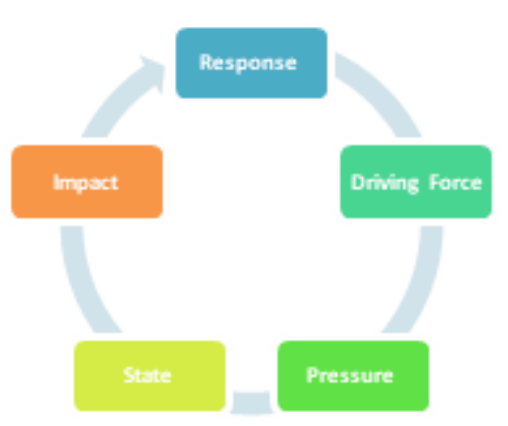

Figure 2. DPSIR methodology.

The Convention on Biological Diversity (CBD) has urged parties to develop national and regional biodiversity targets, using the strategic plan and its global Aichi targets [20]. The Aichi global target emphasis that 17 percent of terrestrial and inland water areas, especially areas of particular importance for biodiversity and ecosystem services are conserved through well-connected systems of protected areas and effective conservation measures. Accordingly, India has developed 12 national biodiversity targets and the target 5 (sustainable management of fisheries); target 6 (ecologically representative areas, especially importance for species, biodiversity, ecosystem services are conserved), and target 8 (ecosystem services related to water, human health, livelihood and wellbeing's are enumerated and measured) are related to inland fisheries [21].The present study has brought out few recommendations to integrate biodiversity considerations into the inland aquatic system towards increasing the aquatic diversity.

\section{Governance}

India is committed to several international conventions, Code of conduct and guidelines towards conserving land-based aquatic biodiversity resources namely, Convention on Biological Diversity (CBD) 1993; Convention on Conservation of Migratory Species (CMS), 1982; Ramsar Convention on Wetlands, 1982; United Nations Framework Convention on Climate Change (UNFCCC); FAO Code of Conduct for Responsible Fisheries (CCRF); Food and Agriculture Organisation (FAO) guidelines on eco-labelling for inland fisheries; FAO technical guidelines for aquaculture certification and FAO technical guidelines for small scale fisheries, and so on. The National Environmental Policy, 2006 emphasis to conserve the critical environmental resources and to protect threatened/endangered species of special importance to sustaining life. The draft National Inland Fisheries and Aquaculture Policy (NIFAP) 2018 envisage to create an enabling environment for sustainable development for inland fisheries and aquaculture in the country. It also stress on conserving indigenous fisheries resources and restoration of natural productivity through ecosystem restoration; habitat conservation measures for protection and rehabilitation of native fish stocks; seed ranching of native stock by developing dedicated seed production units and emphasised that fisheries management to be integral in river management.
To conserve the wetlands, a wetlands (Conservation and Management) Rule, 2017 was notified under the provisions of the Environment (Protection) Act, 1986. The Ministry of Urban Development (MoUD) has issued an advisory on conservation and restoration of water bodies in urban areas and a river conservation programme was initiated with the launch of Ganga Action Plan (GAP) in 1985 and was expanded to cover other rivers under the National River Conservation Plan (NRCP) [22].

\section{Recommendations}

The study carried out under the Centre for Biodiversity Policy and Law (CEBPOL) Programme has brought few recommendations for restoring the inland water resources and its biodiversity [23], these recommendations are as follows:

\section{Conservation of fish genetic resources}

It is important to develop a database on the indigenous fishery resources of India and a protocol for seed ranching of indigenous fish species need to be developed. Seed collected from the original parents should be used for ranching and the viability of the localized species should be improved through in-situ conservation, hatcheries and brood banks.

\section{Valuation of ecosystem services}

Inland open water bodies provide several valuable ecosystem services; hence it is important to value the ecosystem services of the inland water bodies and its associated habitat.A suitable Indian model for valuation of ecosystem services needs to be developed for the benefit of the policy makers and planners.

\section{Conservation and restoration of inland aquatic ecosystems}

Water quality plays an important role in providing ecosystem services. Hence it is recommended to prepare an ecosystem health card for major rivers, lakes and wetlands; environmental flow requirements must be made mandatory for fish to migrate from upstream to the downstream; fish passes/diversion cannel for dams and barrages should must be made mandatory as a part of Environmental Impact Assessments while providing approvals for river valley projects; strict implementation of existing rules against using fishing gears or methods must be ensured (destructive fishing gear such as fixed/stake nets, zero or small mesh nets and fishing methods such as dynamiting, poisoning, capturing juveniles and brooders of declining fish species and are detrimental to natural fish populations and aquatic biodiversity).

\section{Co-management}

Co-management represents new approach to fisheries management. It is strongly recommended that fishing in open water resources should be under strong co-management platform involving Corporative Societies, Self Help Groups and Biodiversity Management Committees to ensure responsible fishing practices. Co-management practices will 
Citation: Jacob TC, VR Suresh, VV Sugunan, B Meenakumari. Conservation of aquatic biodiversity for achieving india's food, nutritional and livelihood security with special reference to inland fisheries and aquaculture. J Fish Res 2020;4(1):30-35.

improve sustainable fishing, equity and help in efficient management of aquatic resources.

\section{Regulatory Framework for fresh water Aquaculture}

The inland open water fisheries and the freshwater aquaculture are not covered under any strong regulatory frameworks, hence it is recommended to form a statutory institution to regulate activities in inland fisheries and freshwater aquaculture to ensure that biodiversity is not compromised while pursuing production targets. Aquaculture practices are known to cause environmental degradation (due to farm outfalls like chemicals, feeds, etc.) of adjoining water bodies, ground water, agricultural fields, drinking water sources, open waters and land. Adverse impact of these must be assessed and regulated to avoid or minimise such degradation. Fool-proof facilities to prevent escape of fish from aquaculture to open water bodies must be ensured while granting permission to aquaculture ventures.

\section{Hatcheries}

As a measure of diversifying aquaculture species, the existing single species fish seed hatcheries in the public sector must be converted into multi-species fish seed hatcheries. State level action plan is required to produce and maintain brood stocks for all important native germplasm under the guidance of national research Institutes. It is recommended that the prevailing practice of mixed spawning of different species of Indian major carps must be stopped through legislative or enforcement measures and a Best Management Practices protocols for culture systems like cage culture, intensive aquaculture, stock management, seed production, etc need to be developed.

\section{Certification / Eco-labeling}

Fish produced through biodiversity friendly means and the distribution of fish seed from hatcheries must be brought under a strong certification (Green Certification and eco-labeling) regime. Develop protocols for branding, organic certification, green labeling, eco-labeling must be developed and ensuring compliance to such protocol is required by identification, creation, accreditation and empowerment of suitable organization.

\section{Incentive mechanisms}

Schemes provided and beneficiaries should be encouraged to provide incentives for the biodiversity friendly practices such as: promoting indigenous varieties, following responsible fishing practices, organic aquaculture and bringing unused water bodies under sustainable fishing practices. There is a need to improve and stabilise farm productivity and income generation for the rural poor by encouraging integrated farming practices, fish culture in watershed ponds and water harvesting structures. One-stop aqua-shops must be promoted, with proper registration and accreditation for ensuring free movement of disease-free and quality seed, brood stock and other inputs and accessories for shrimp and fish culture.

\section{Ornamental fish trade}

Policy should be framed to ensure compliance of quarantine measures and the existing quarantine mechanisms must be strengthened for the trans-boundary import of seeds of ornamental fish species. Illegal trade of native/endemic ornamental fishes collected from wild stocks of ornamental fishes from rivers, lakes must be curbed and the monitoring mechanism need to be strengthened. There is also a need for bringing out and implementing guidelines for hobbyists and ornamental fish keepers about holding and disposal of stock to avoid these species from reaching natural water bodies.

\section{Invasive Alien Species}

There is a need to prepare a database on invasive alien species and their pathways and strategies must be developed for managing or controlling them based on risk assessment studies. Voluntary guidance must be prepared to avoid unintentional introduction of Invasive Alien Species (pets, aquarium species, terrarium species, live bait and live food) associated with trade of live organisms. There must be easy-to-use pictorial guidelines to enable the customs officers to identify those invasive species. The Central Government must create norms for uniform quarantine measures for introduction of species and encourage state Governments to follow them.

\section{Strengthening the implementation of the BD Act}

It is important to map the unique and ecologically important inland water bodies (having high endemism, rare and threatened species, key stone species, species of evolutionary significance, wild relatives, migratory routes and spawning and breeding areas) and to protect these areas by designation them as Biodiversity Heritage Sites or fish sanctuaries. The rare and threatened aquatic species need to be rehabilitated through various breeding programmes. The collection of fish or shrimp seed from the wild must be stopped through appropriate legal or regulatory measures; and the Biodiversity Management committees need to be strengthened at the local level for conserving the inland aquatic genetic resources.

\section{Conclusion}

The inland water bodies provide vital ecosystem services for human development, poverty reduction and offers habitat for biodiversity. India is rich in aquatic resources and has diverse aquatic genetic resources, but these resources are declining significantly due to various multiple anthropogenic factors. The policy analysis study carried out under the CEBPOL programme, recommends to restore the unutilized water bodies such as, wetlands, tanks, canals, beels and to bring those areas under cultivation practices towards providing livelihood for the local communities. It is suggested to strengthen the regulatory measures such as: maintaining minimum environmental flows in the rivers; providing fish passes while undertaking projects across dams and river; curbing the collection of wild stocks from the inland water bodies and managing controlling the spread of aquatic invasive alien species, etc. Also it is recommended to map the indigenous aquatic biodiversity 
available in pristine stretches and to value the biodiversity significant inland water bodies for the benefit of the policy makers. The implementation of the Biological Diversity Act need to be strengthened at the local level and the Biodiversity Management Committees should take part in documenting and conserving the aquatic genetic resources for the human wellbeing.

\section{References}

1. Convention on Biological Diversity, 2019.

2. Chandra K, Gopi KC, Rao DV, et al. Current status of freshwater faunal diversity in India. Zoological Survey of India. 2017; 1-624.

3. Das MK, Samanta S, Saha PK. Riverine health and impact on fisheries in India. Central Inland Fisheries Research Institute. 2007.

4. Lal KK, Jena JK, NBFGR: A center for aquatic genetic resource management research in India. International Agrobiodiversity Congress. Sci. 2016.

5. National draft Inland Fisheries and Aquaculture Policy. Department of Animal Husbandry, Dairying and Fisheries. Ministry of Agriculture and Farmers Welfare,Government of India, 2019.

6. Sharma AP, Das MK, Samanta S. Health of inland aquatic resources and its impact on fisheries. 2014.

7. Sundarban Biosphere Reserve (Web Source: http:// sundarbanbiosphere.org).

8. Aldababseh A, Thomson JC, Terminal evaluation report on Mainstreaming Coastal and MarineBiodiversity into Production Sectors in the East Godavari River Estuarine Ecosystem, GEF-United Nations Development Programme report. 123, 2019.

9. Annual Report 2017-18. Published by DAHDF, MoA \&FW, GoI.

10. Scheme on Development of Inland Fisheries and Aquaculture - An Analysis. Standing committee on Agriculture, DAHDF, MoAFW, GoI. 2017-2018.

11. Vision 2050, Central Institute of Brackish water Aquaculture, ICAR, Tamil Nadu.

12. Singh AK, Sarma D. Aquatic resources and fish diversity of the Himalayas. Narendra Publishing House New Delhi $2017 ; 345$.
13. National draft Inland Fisheries and Aquaculture Policy. DAHDF, MoAFW, GoI. 2019.

14. Pimentel D, et al. Economic and environmental threats of alien plant, animal and microbe invasions. Agr Ecosyst Env. 2001; 84:1-20.

15. MoEFCC and GIZ. The Economics of Ecosystems and Biodiversity, TEEB India Initiative: Interim Report Working Document. 2014; 92.

16. Singh AK, Akhtar MS. Coldwater fishery resources, fish diversity and its sustainable management in India. In: Faunal Diversity in India. Narendra Publishing House. 2015; 397-412.

17. Singh AK. Emerging alien species in Indian aquaculture: Prospects and threats. J Aquat Biol Fisher. 2014; 2: 32-41.

18. Huntley BJ, Redford KH. Mainstreaming Biodiversity in practice: a STAP advisory document Global Environmental Facility. Washington, 2014.

19. Thomson CJ, et al, State of Environment Report, Tamil Nadu. Department of Environment, Government of Tamil Nadu, Chennai, 2006; 129.

20. Strategic Plan for Biodiversity 2011-2020, including Aichi Biodiversity Targets.

21. National Biodiversity Action Plan, Addendum 2014 to NBAP 2008. MoEFCC, GoI.

22. India's Fifth National Report to the Convention on Biological Diversity. MoEFCC, 2014.

23. Jacob C, Sugunan VV, Meenakumari B. Mainstreaming Biodiversity into Inland Fisheries and Aquaculture: A Key for food and nutritional security. Centre for Biodiversity Policy and Law Programme, National Biodiversity Authority. 2019.

${ }^{*}$ Correspondence to

C Thomson Jacob

Centre for Biodiversity Policy and Law

National Biodiversity Authority

Dayananda Sagar University

Chennai, India

E-mail: thomsonjacob70@gmail.com 